\title{
Accent Discrimination and the Test of Spoken English: A Call for an Objective Assessment of the Comprehensibility of Nonnative Speakers
}

\author{
Beatrice Bich-Dao Nguyen $\uparrow$
}

Immigrants to the United States have been a source of national pride, but also the object of national prejudice. At times, employers have used claims of "unintelligible English" to deny jobs to accented, but otherwise qualified, applicants. However, these claims may be mere pretense to discrimination based on national origin, a violation of title VII of the Civil Rights Act of 1964. In such cases, courts must make a judgment about an individual's comprehensibility, and thus, his or her qualifications. These determinations are subjective and highly vulnerable to the sways of prejudice. In this Comment, the author calls for the use of an objective test to determine the comprehensibility of an individual's speech. She offers the Test of Spoken English, a standardized test administered nationwide by the Educational Testing Service, as a tool available to both parties and the courts in accent discrimination litigation.

\section{INTRODUCTION}

Immigrants from all parts of the world come to the United States in the hope of building a better hife for themselves and their children. For them, America embodies a land of opportunity, extending to each and every immigrant the hope of attaining the American Dream. ${ }^{1}$ In return,

$\dagger$ B.S.F.S. 1991, School of Foreign Service, Georgetown University; J.D. candidate 1994, Boalt Hall School of Law, University of California, Berkeley. Copyright $\odot 1993$ by California Law Review, Inc. and Asian Law Journal.

I would like to thank Professor Jan Vetter for his assistance and encouragement. This Comment benefited greatly from his insight, guidance, and patient listening. I am indebted to my editors, Frank Cialone, Eric Lai, and Brian Torres, and friends and colleagues on Asian Law Journal and California Law Review for their hours of work. Special thanks to Professor Bill Ong Hing, Larry Adams, Danny Cloherty, Brian Lee, and Jasmin Patel for their contributions to earlier drafts of this Comment.

This Comment is dedicated to my mother and father, Simone Bui Nguyen and Phuoc Nguyen.

1. The American tradition of welcoming immigrants from all parts of the world is embodied in the words inscribed on the Statue of Liberty:

Give me your tired, your poor, 
these immigrants bring with them their cultures and languages, enriching this nation's diversity. As they settle into their new lives and learn the customs of their adopted country, these new Americans reveal their status as immigrants through their accents.

Every individual has an accent that "carries the story" of who she is and that may identify her race, national origin, profession, and socioeconomic status. ${ }^{2}$ Yet we generally refer to an accent to indicate a "difference from some unstated norm of nonaccent, as though only some foreign few have accents." ${ }^{\prime 3}$ As immigrants move into the work force to pursue "promises of freedom, equality, and economic opportunity,"4 they may encounter the barrier of accent discrimination ${ }^{5}$ "a closed eco-

\footnotetext{
Your huddled masses yearning to breathe free,

The wretched refuse of your teeming shore,

Send these, the homeless, tempest-tost, to me,

I lift my lamp beside the golden door!
}

-Emma Lazarus

In recent years, however, this tradition has become imperiled by growing anti-immigration sentiments, spurred on by a declining economy and xenophobic fears. In a recent poll of 1162 California residents conducted by the Los Angeles Times, more than half of the respondents favored paring back legal immigration because of concerns regarding a drain on government services, loss of jobs, overcrowding, and an increase in crime. Dianne Klein, Majority in State are Fed Up with Illegal Immigration, L.A. TIMEs, Sept. 19, 1993, at A1. Although 52\% of the respondents said that they were concerned that a crackdown on illegal immigration may lead to discrimination against all immigrants, $43 \%$ were not bothered by this possibility. Interestingly, $70 \%$ of the respondents indicated that they had difficulty determining who was a legal immigrant. Id.; see Suzanne Espinosa \& Benjamin Pimentel, Anger at Immigration Overflow: Backlash Against Asians, Latinos, S.F. Chron., Aug. 27, 1993, at A1 (reporting stories of legal immigrants and American-born Asians or Latinos who have suffered physical or verbal abuse because of anti-immigration sentiments).

2. Mari J. Matsuda, Voices of America: Accent, Antidiscrimination Law, and a Jurisprudence for the Last Reconstruction, 100 YALE L.J. 1329, 1329 (1991).

3. Id. at 1330. Reluctantly, I follow this common usage of "accent" in this Comment, using the terms "accented individuals" and "individuals with accents" to refer to people with accents commonly associated with foreign birth. Likewise, I refer to "nonaccented individuals" and "individuals without accents" as people with accents which generally suggest that they werc raised in the United States speaking English as their first language.

4. Fragante v. City of Honolulu, 888 F.2d 591, 596 (9th Cir. 1989), cert. denied, 494 U.S. 1081 (1990).

5. A recent General Accounting Office (GAO) report cited widespread discrimination against "foreign-sounding" job applicants. U.S. GEN. ACCOUNTING OFFICE, IMMIGRATION REFORM: EMPLOYER SANCTIONS AND THE Question of Discrimination 5-6 (1990) [hereinafter GAO REPORT]. In one example:

A pair of testers applied for a position with a manufacturer that was listed under "shipping" in the Sunday Chicago Tribune. The advertisement specified that the company wanted a "dependable, hardworking person" and that applicants should contact "Bill." The Hispanic tester called the specified phone number and, after inquiring about the job, was told by Bill that the position was filled. The Anglo tester called 15 minutes later and Bill invited him for an interview for later that day. After a 15-ninute interview, the Anglo tester was offered the position. The two testers phoned about the job in the same manner to the same person. The only discernible difference in the phone contact was the Hispanic tester's accent.

Id. at 49. Survey data showed that $10 \%$ of employers nationwide, by their own admission, discriminate against "foreign-sounding" and "foreign-looking" applicants. Id. at 38. Interestingly, a significant percentage of employers in four cities with high Hispanic and Asian populations 
nomic door based on national origin discrimination."6

Fearing the stigina that accoinpanies a foreign accent, ${ }^{7}$ some immigrants have turned to speech tutors, private companies, and colleges to eliminate or reduce their accents, even when their accents do not impair comprehensibility. ${ }^{8}$ Immigrants' perceived need to eliminate all traces of their accents in order to obtain employment or advance their careers ${ }^{9}$ is unfortunate. Their accents indicate their national origin as outside of the United States-a fact that immigrants should not have to feel compelled to conceal in order to gain acceptance or employinent in a country that purportedly values diversity and differences among individuals. "To tell the minority group member that he must discard the characteristic manifestations of his national identity in order to have a truly equal and fair opportumity to coinpete for a job is to tell lim that lis identity has no place in American society."10

Courts recognize that discrimination against accent may function as the equivalent of discrimination against national origin, ${ }^{11}$ which is prohibited under title VII of the Civil Rights Act of 1964 ("title VII" or "the

reported discriminatory employment practices: $29 \%$ in Los Angeles, $21 \%$ in New York City, $19 \%$ in Chicago, and $18 \%$ in Miami. Id.

In the same year, the Coalition for Humane Immigrant Rights of Los Angeles (CHIRLA) found that $31.7 \%$ of accented job applicants in Los Angeles were treated less favorably than other applicants and that accented callers were not considered for the job in $20.1 \%$ of the calls. AsIAN PaC. Am. Legal CTr. of S. Cal., Accent Discrimination (1991) (on file with author).

6. Fragante, 888 F.2d at 596.

7. The stigma associated with accent and the ready acceptance of accent discrimination is discussed in Part I.C.2.

8. See Raymond Hernandez, Immigrants Use Diction Lessons to Counter Bias, N.Y. TIMES, Mar. 2, 1993, at A12; Jolie Solomon, Lose That Thick Accent to Gain Career Ground, WALL ST. J., Jan. 4, 1990, at A1 (noting emergence of "accent reduction classes" for foreign-born professional workers "whose careers have stalled because of thick accents, even though their grammar and vocabulary skills are good"); see also Ruth Hamel \& Tim Schreiner, Speak English, Troops, AM. DEMOGRAPHICS, Jan. 1989, at 66 (stating that the influx of Asians and Hispanics in California has created strong demand for accent-modification courses).

Camps within the scientific community disagree whether such classes are necessary since they differ fundamentally over whether accent constitutes an impediment at all. See Matsuda, supra note 2, at 1363-67 (discussing the debate between sociolinguists, who view accent as a social and cultural creation, and speech pathologists, who view accent as an impediment).

9. See Hernandez, supra note 8; Peggy Landers, Accent on Understanding, Miami HeRald, Mar. 6, 1986, at 1B; Solomon, supra note 8; Tracy Wilkinson, An Accent Could be an Invitation to Bias, L.A. TIMES, Apr. 23, 1990, at B1.

10. Stephen M. Cutler, Comment, A Trait-Based Approach to National Origin Claims Under Title VII, 94 YALE L.J. 1164, 1177-78 (1985).

11. See, e.g., Fragante v. City of Honolulu, 888 F.2d 591, 596 (9th Cir. 1989), cert. denied, 494 U.S. 1081 (1990); Carino v. University of Okla. Bd. of Regents, 750 F.2d 815, 819 (10th Cir. 1984) (upholding a finding of discrimination in demoting an employee because of his national origin and related accent: "A foreign accent that does not interfere with a Title VII claimant's ability to perform duties . . . is not a legitimate justification for adverse employment decisions."); Berke v. Ohio Dep't of Pub. Welfare, 628 F.2d 980, 981 (6th Cir. 1980) (finding that plaintiff was denied "two positions within the Department because of her accent which flowed from her national origin"); Shieh v. Lyng, 710 F. Supp. 1024, 1032 (E.D. Pa. 1989) (upholding the district court's denial of plaintiff's discrimination claim but recognizing that national origin and accent discrimination are 
Act"). ${ }^{12}$ Specifically, the Ninth Circuit has stated:

Accent and national origin are obviously inextricably intertwined in many cases. It would therefore be an easy refuge in this context for an employer unlawfully discriminating against someone based on national origin to state falsely that it was not the person's national origin that caused the einployinent or promotion problem, but the candidate's inability to ineasure up to the commumcations skills demanded by the job. We encourage a very searching look by the district courts at such a claim. ${ }^{13}$

In addition, the Equal Employment Opportunity Commission (EEOC) has declared that discrimination based on a person's manner of speech or accent inay constitute national origin discrimination under title VII. ${ }^{14}$

Employers, however, have a countervailing right to require sufficient communication skills from employees. ${ }^{15}$ Indeed, title VII was not intended to "diminish traditional inanagement prerogatives,"16 and it allows an employer the "discretion to choose among equally qualified candidates, provided the decision is not based upon unlawful criteria." 17 Nevertheless, the consistency with which employers raise the "unintelligible English" defense in accent cases $^{18}$ and the readiness of courts to uphold it $^{19}$ threaten to nullify title VII's protection against national ori-

related), aff'd without op., 897 F.2d 523 (3d Cir. 1990); Lee v. Walters, No. 85-5383, 1988 U.S. Dist. LEXIS 11336, at *18 (E.D. Pa. Oct. 11, 1988) (citing Carino with approval).

12. 42 U.S.C. $\S \S 2000 \mathrm{e}$ to $2000 \mathrm{e}-17$ (1988 \& Supp. 1990). The recently passed Civil Rights Act of 1991 does not alter protection against accent discrimination extended under the 1964 Act. Rather, the 1991 Act provides compensatory and punitive damages for intentional discrimination; codifies the concepts of "business necessity" and "job-related" enunciated in Griggs v. Duke Power Co., 401 U.S. 424 (1971); overturns the Supreme Court's decision in Wards Cove Packing Co. v. Atonio, 490 U.S. 642, 656-60 (1989) (holding that plaintiffs must identify specific employment practices that cause a significant disparate impact on nonwhites, that defendants carry only a burden of production for the business justification for the challenged employment practices, and that the burden of persuasion remains on plaintiffs); provides statutory guidelines for the adjudication of disparate impact cases under title VII of the 1964 Act; and extends the scope of relevant civil rights statutes. Civil Rights Act of 1991, Pub. L. No. 102-166, 1991 U.S.C.C.A.N. (105 Stat.) 1071, 1071.

13. Fragante, 888 F.2d at 596.

14. EEOC Compl. Man. (CCH) § 623.10, 凤 4010 (1986).

15. Professor Matsuda defines the problem this way:

The puzzle in accent cases is that accent is often derivative of race and national origin. Only Filipino people speak with Filipino accents. Yet, within the range of employer prerogatives, it is reasonable to require communication skills of employees. The claim that accent impedes job ability is often made with both sincerity and economic rationality. How, then, should Title VII squeeze between the walls of accent as protected trait and speech as job requirement?

Matsuda, supra note 2, at 1348 .

16. Texas Dep't of Community Affairs v. Burdine, 450 U.S. 248, 259 (1980) (quoting United Steelworkers of Am. v. Weber, 443 U.S. 193, 207 (1979)).

17. Id.

18. Employers raising this defense to explain adverse employment decisions argue, based on subjective assessments, that job applicants' accents would have impeded job performance because the applicants' spoken English is not sufficiently comprehensible.

19. See, e.g., Fragante v. City of Honolulu, 888 F.2d 591, 599 (9th Cir. 1989) (holding that the 
gin discrimination by leaving the determination of intelligibility to the subjective assessment of employers and courts.

Title VII should protect employees and potential employees from accent discrimination while preserving the interests of employers in hiring and promoting qualified individuals. To further these goals, courts need an objective and accurate method of assessing whether a plaintiff's accent is sufficiently comprehensible for a specific job. This Comment will suggest such a method.

Part I of this Comment discusses title VII of the Civil Rights Act of 1964 and the difficulties of applying it to accent discrimination cases. It concludes by reviewing two recent accent discrimination cases. Part II discusses the dangers of relying on subjective assessments and the need for an objective tool in the adjudication of accent discrimination cases. It then presents the Educational Testing Service's Test of Spoken English (TSE) and argues for its use in evaluating a plaintiff's accent. Part III explores the application of the TSE as an aid to parties and courts in accent discrimination cases.

\section{Title VII AND ACCENT Discrimination}

In passing title VII, Congress made the momentous pronouncement that sex, race, color, religion, and national origin are not relevant to the selection, evaluation, or compensation of employees. Except for religion, these categories sliare a single distinctive aspect: each is an immutable trait with which an individual is born and which is beyond her power to alter. ${ }^{20}$ Congress intended, therefore, to compel employers to focus on individual qualifications, rather than on group identification, in making employment decisions. ${ }^{21}$

employer legitimately passed over plaintiff for a clerking job because his Filipino accent had a deleterious effect on his oral communication), cert. denied, 494 U.S. 1081 (1990); Sirajullah v. Illinois State Medical Inter-Ins. Exch., No. 86 C 8668, 1989 WL 88316, at *2 (N.D. Ill. Aug. 1, 1989) (concluding that an insurance company reasonably decided not to renew plaintiff's medical malpractice insurance because his accent might have impeded the insurer's ability to defend a malpractice suit against him); Tran v. City of Houston, 35 Fair Empl. Prac. Cas. (BNA) 471 (S.D. Tex. 1983) (finding plaintiff's spoken English inadequate for a job that included explaining the law to building owners and helping them devise plans for energy conservation, despite his service as an interpreter during the Vietnam War).

20. Strictly speaking, a person's religion is not immutable although it may be deeply rooted. Nevertheless, it finds protection under title VII presumably because of the fundamental respect accorded to it by the U.S. Constitution. See Doe v. First Nat'l Bank, 668 F. Supp. 1110, 1112 (N.D. III. 1987). But see Rodriguez v. Taylor, 569 F.2d 1231, 1236 (3d Cir. 1977) (categorizing religion as an immutable personal characteristic protected under Title VII).

21. See the interpretive memorandum from Senators Case and Clark, key supporters of the 1964 Act, wherein they wrote that title VII "expressly protects the employer's right to insist that any prospective applicant, Negro or white, must meet the applicable job qualifications. Indeed, the very purpose of the title VII is to promote hiring on the basis of job qualifications, rather than on the basis of race or color." 110 CoNG. Rec. 7247 (1964). The Supreme Court has recognized the 


\section{A. Accent as an Aspect of an Immutable Trait}

None of the legislative debates or committee reports accompanying title VII discusses the issue of what constitutes discrimination on the basis of national origin. ${ }^{22}$ In an effort to fill this gap, the EEOC defines national origin discrimination as including, but not limited to, the denial of equal employment opportumity to a person because of her actual or ancestral place of origin, or because she has the physical, cultural, or linguistic characteristics of a national origin group. ${ }^{23}$ This includes discrimination based on an accent associated with foreign birth. ${ }^{24}$ The EEOC has found, for example, that the use of "Fluency-in-English requirements, such as denying employment opportunities because of an individual's foreign accent, or inability to communicate well in English," may constitute national origin discrimination. ${ }^{25}$

Evidence that adults generally retain their natural accents supports the EEOC's determmation and furthers Congress' intent of prohibiting discrimination based on immutable traits. Research in language acquisition shows that most people retain their original accents when they acquire a second language after childhood. ${ }^{26}$ One study of 109 speakers found that an individual's age at the time of second language acquisition is critical to the retention of an accent: when a child acquires a new language before age seven, there is no accent transfer; from ages seven to nine, there is a strong likelihood of acquiring accent-free speech in the second language; from nine to eleven, chances drop to about 50\%; and froin adolescence onward, chances of accent-free second language acqui-

authoritative weight of this memorandum, see, e.g., Firefighters v. Stotts, 467 U.S. 561, 581 n.14 (1984), and views it as representative of Congress' intent to force employers to focus on qualifications alone. Price Waterhouse v. Hopkins, 490 U.S. 228, 243 (1989); see also Griggs v. Duke Power Co., 401 U.S. 424, 429-30 (1971) ("The objective of Congress in the enactment of Title VII . . . was to achieve equality of employment opportunities and remove barriers that have operated in the past to favor an identifiable group of white employees over other employees.").

Although many of the legislators' statements focused specifically on race rather than on the other enumerated traits in the legislative history, the Supreme Court does not "limit [its interpretations of] their statements to the context of race," but instead interprets them "as general statements on the meaning of Title VII." Price Waterhouse, 490 U.S. at 243-44 n.9.

22. 'The only direct definition given the phrase 'national origin' is the following remark made on the floor of the House of Representatives by Congressman Roosevelt, Chairman of the House Subcommittee which reported the bill: 'It means the country from which you or your forebears came.'" Espinoza v. Farah Mfg. Co., 414 U.S. 86, 89 (1973) (quoting 110 CoNG. REC. 2549 (1964)).

23. 29 C.F.R. § 1606.1 (1992).

24. Guidelines on Discrimination Because of National Origin, 45 Fed. Reg. 85,632 (1980), state that " $t$ t]o prove a national origin claim, it is enough to show that the complainant was treated differently than others because of his or her foreign accent, appearance or physical characteristics."

25. 29 C.F.R. $\$ 1606.6$ (1992) (footnotes omitted); see also 1 EEOC Compl. Man. $\$ 623.10$ (1986) (stating that discrimination on the basis of a person's manner of speaking or accent may constitute national origin discrimination under title VII).

26. See Michael H. Long, Maturational Constraints on Language Development, in 12 STUDIES in Second Language AcQuisition 251, 265, 274 (1990). 
sition are minimal. ${ }^{27}$ Consequently, when employers use accent as a hiring criterion, they are discriminatimg against a trait which may be beyond the individual's power to control and which is indicative of national origin, a classification protected under title VII.

\section{B. The Structure of Title VII Litigation}

A title VII plaintiff may prove discrimination under a "disparate treatment theory" or a "disparate impact theory." Although plaintiffs alleging accent discrimmation can bring suit under either theory, cases are typically brought and analyzed as disparate treatment claims. ${ }^{28}$

\section{Disparate Treatment Claims}

Both individual and group claims may rest on a disparate treatment theory. Individual claims nornally concern allegations of different and unfavorable treatment of a simgle employee or applicant. Group or pattern-and-practice disparate treatment claims normally involve a presentation of statistical evidence that attempts to demonstrate that all employees or apphicants of a particular protected group tend to be treated unequally.

In either case, the plaintiff must prove a discriminatory motive on the part of the employer ${ }^{29}$ and must carry the initial burden of establishing a prima facie case of disparate treatınent. To establish a prima facie case of national origin discrimination, a plaintiff must prove (1) that she has an identifiable national origin, ${ }^{30}(2)$ that she applied and was qualified for the job for which the employer was seeking applicants, (3) that she was rejected despite her qualifications, and (4) that, after her rejection, the position remained open and the employer continued to seek

27. See Sonia Tahta et al., Foreign Accents: Factors Relating to Transfer of Accent From the First Language to a Second Language, 24 LANGUAGE \& SPEech 265 (1981).

28. See, e.g., Fragante v. City of Honolulu, 888 F.2d 591, 594-95 (9th Cir. 1989), cert. denied, 494 U.S. 1081 (1990); Carino v. University of Okla. Bd. of Regents, 750 F.2d 815, 818-20 (10th Cir. 1984); Berke v. Ohio Dep't of Pub. Welfare, 628 F.2d 980, 981 (6th Cir. 1980); Shieh v. Lyng, 710 F. Supp. 1024, 1030-31 (E.D. Pa. 1989), aff'd without op., 897 F.2d 523 (3d Cir. 1990); Mandhare v. W.S. LaFargue Elem. Sch., 605 F. Supp. 238, 241 (E.D. La. 1985), rev'd without op., 788 F.2d 1563 (5th Cir.), and cert. denied, 479 U.S. 931 (1986); Hou v. Pennsylvania Dep't of Educ., 573 F. Supp. 1539, 1544-46 (W.D. Pa. 1983).

Disparate treatment analysis more readily lends itself to accent discrimination cases than does disparate impact analysis because the former focuses on the plaintiff's particular accent. Such a focus simplifies the litigation since the analysis of the claim is always specific to the individual and the facts surrounding her claim.

29. See, e.g., International Bhd. of Teamsters v. United States, 431 U.S. 324, 335 n.15 (1977).

30. Courts have held that title VII extends to any person whose manner of speaking and accent marks her national origin as outside the United States, regardless of whether her specific country of origin is readily apparent. Thus, an employer may have to produce evidence that it did not discriminate against an individual even if the employer, or the average American, would be unable to identify the applicant's country of origin through her speech. See, e.g., Berke v. Ohio Dep't of Pub. Welfare, No. C-2-75-815, 1978 WL 13924, at *6 (S.D. Ohio June 6, 1978), aff'd, 628 F.2d 980 (6th Cir. 1980). 
applicants from persons of the plaintiff's qualifications. ${ }^{31}$ By establishing a prima facie case, the plaintiff in a title VII action creates a rebuttable "presumption that the employer unlawfully discriminated against" her. ${ }^{32}$ Moreover, there is a presumption that the latter two acts, otherwise unexplained, are likely based on consideration of impermissible factors. ${ }^{33}$

Once the plaintiff establishes a prima facie case, the burden shifts to the defendant to articulate a legitimate, nondiscriminatory reason for the adverse employment decision. ${ }^{34}$ To rebut the plaintiff's prima facie case, "the defendant must clearly set fortl, through the introduction of admissible evidence, the reasons for the plaintiff's rejection."35 However, the defendant need only produce some evidence that the decision was made on nondiscriminatory grounds. The plaintiff bears the ultimate burden of persuasion. ${ }^{36}$

If the defendant successfully rebuts the prima facie case, the plaintiff must then show that the defendant's rationale for discrimination was pretextual. ${ }^{37}$ The plaintiff may do this either directly, by showing that the employer more likely liad a discriminatory motive, or indirectly, by showing that the employer's proffered reason is not worthy of credence. ${ }^{38}$

The defendant, rather than rebutting the plaintiff's prima facie case, may justify explicit discrimination by invoking the bona fide occupational qualification (BFOQ) exception to disparate treatment. ${ }^{39}$ The courts have construed the BFOQ exception as an affirmative defense for which the employer bears the initial burden of production and the ultimate burden of persuasion. ${ }^{40}$ Moreover, the BFOQ defense "provides

31. McDonnell Douglas Corp. v. Green, 411 U.S. 792, 802 (1973). Although McDonnell Douglas Corp. involved racial discrimination, the Supreme Court articulated these four elements of a prima facie case for application in all private, non-class action suits challenging employment discrimination. Id. at 800-02.

32. Texas Dep't of Community Affairs v. Burdine, 450 U.S. 248, 254 (1981).

33. See id.; Furnco Constr. Corp. v. Waters, 438 U.S. 567, 577 (1978).

34. McDonnell Douglas, 411 U.S. at 802.

35. Texas Dep't of Community Affairs, 450 U.S. at 255.

36. Id. at $256-57$.

37. McDonnell Douglas, 411 U.S. at 804; see also St. Mary's Honor Ctr. v. Hicks, 113 S. Ct. 2742 (1993) (holding that, because a plaintiff asserting a disparate treatment claim bears the ultimate burden of persuasion on the issue of intentional discrimination, a fact finder's rejection of an employer's proffered reasons for the adverse employment decision does not necessarily compel a finding for the plaintiff).

38. Texas Dep't of Community Affairs, 450 U.S. at 256.

39. Section 703(e)(1) of the Civil Rights Act of 1964, 42 U.S.C. $\S 2000 \mathrm{e}-2(\mathrm{e})(1)$ (1988), provides in pertinent part:

[I]t shall not be an unlawful employment practice for an employer to hire and employ employees ... on the basis of ... religion, sex, or national origin in those certain instances where religion, sex, or national origin is a bona fide occupational qualification reasonably necessary to the normal operation of that particular business or enterprise . . . .

Note that the law does not recognize race as ever being a BFOQ.

40. See Price Waterhouse v. Hopkins, 490 U.S. 228, 248 (1989) (plurality opinion) (discussing title VII in the gender-discrimination context and stating that "[w]hen an employer has asserted that gender is a BFOQ within the meaning of $\S 703(\mathrm{e})$... we have assumed that it is the employer who 
only the narrowest of exceptions to the general rule requiring equality of employment opportunities."41 To qualify as a BFOQ, a discriminatory job qualification must "affect an employee's ability to do the job,"42 and "must relate to the 'essence' or to the 'central mission of the employer's business." "43

\section{Disparate Impact Claims}

Under a disparate impact theory, discrimmation results when facially neutral employment policies and practices even-handedly applied to all employees and applicants have a disproportionate, negative effect on members of protected groups. ${ }^{44}$ Disparate impact doctrine thus focuses on policies or practices that constitute part of an employer's standard operating procedure, rather than on isolated or sporadic discriminatory actions. Consequently, claims under this theory must demonstrate that the employer's practices cause broader harm than the harn it caused to the plaintiff alone.

The plaintiff establishes a prima facie case by showing that the adverse effects of defendant's employment criteria fall in significant disproportion on the plaintiff's protected group. ${ }^{45}$ Once this disparate impact is established, the burden then shifts to the employer to show that it results from a "business necessity," 46 that is, that the employer's challenged practice "bear[s] a demonstrable relationship to successful perfornance of the jobs for which it [is] used." 47 If the employer meets this

must show why it must use gender as a criterion in employment"); Johnson v. Transportation Agency, 770 F.2d 752, 762-63 (9th Cir. 1985) (analogizing an employer's burden in establishing a BFOQ to the burden in an affirmative action case), aff'd, 480 U.S. 616 (1987); Laugesen v. Anaconda Co., 510 F.2d 307, 313 (6th Cir. 1975) (distinguishing the defense of nondiscrimination, in which the burden of persuasion remains with plaintiff, from the defense of BFOQ, where it shifts to defendant).

41. Dothard v. Rawlinson, 433 U.S. 321,333 (1977).

42. UAW v. Johnson Controls, Inc., 111 S. Ct. 1196, 1205 (1991).

43. Id. (quoting Dothard, 433 U.S. at 333; Western Air Lines v. Criswell, 472 U.S. 400, 413 (1985)).

44. See, e.g., Dothard, 433 U.S. at 331 (noting that the plaintiff need not present additional evidence if the evidence presented demonstrates a job requirement's "grossly discriminatory impact").

45. For example, height and weight requirements for a job which effectively excluded $41 \%$ of the female population from consideration, compared to less than $1 \%$ of the male population, were facially neutral, but discriminatory nonetheless. Id. at 328-31.

46. The business necessity defense is distinct from the narrow statutory BFOQ exception. The BFOQ exception is applicable to disparate treatment claims while the business necessity defense is raised in disparate impact cases. Moreover, the BFOQ exception excuses an explicit discriminatory job qualification while the business necessity defense relates to employment practices that have a disproportionate impact on protected minority groups under title VII.

47. Griggs v. Duke Power Co., 401 U.S. 424, 431 (1971); see also Albemarle Paper Co. v. Moody, 422 U.S. 405, 431 (1975) ("[D]iscriminatory tests are impermissible unless shown, by professionally acceptable methods, to be 'predictive of or significantly correlated with important elements of work behavior which comprise or are relevant to the job or jobs for which candidates are being evaluated." "(quoting 29 C.F.R. $§ 1607.4(\mathrm{c})$ ). 
burden, the plaintiff must show that "other . . . selection devices, without a similarly undesirable . . . effect, would also serve the employer's legitimate interest." 48

The plaintiff need not prove discriminatory motive in making a disparate impact claim. ${ }^{49}$ The plaintiff thus bears a lighter burden of proof than the plaintiff in a disparate treatment case, who must show discriminatory intent. Disparate impact theory requires proof of facts independent of the defendant's state of mind and envisions "the removal of artificial, arbitrary, and unnecessary barriers to employment"50 maintained by facially neutral practices.

\section{The Puzzle of Accent Discrimination Cases in the Title VII Framework}

Accent discrimination cases are distinct from race and gender discrimmation cases, as well as from other national origin discrimination cases, because courts must expressly examme the trait in question and evaluate it in relation to a plaintiff's job qualifications. In contrast, the court in a race or gender discrimination case would consider the plaintiff's immutable trait only to determine if she were in a protected class and would never ask whether the plaintiff's race or gender made her competent for the job in question. ${ }^{51}$

A major challenge in applying title VII to accent discrimination cases is the difficulty in determining which accents actually impede job performance and which "simply differ[] from some preferred norm imposed, whether consciously or subconsciously, by the employer." Trial courts currently lack an objective method to accomplish this task. Instead, they rely heavily on the defendant employer's appraisal and on their own subjective assessment of the accent. ${ }^{53}$ As the next section will show, such assessments are almost unavoidably tainted with the biases and prejudices that make accent discrimination an accepted phenomenon.

48. Albemarle Paper Co., 422 U.S. at 425 (discussing use of general ability tests in racial context).

49. See, e.g., Griggs, 401 U.S. at 432 ("The Company's lack of discriminatory intent is suggested by special efforts to help the undereducated employees . . . . But Congress directed the thrust of the Act to the consequences of employment practices, not simply the motivation.").

50. Id. at 431 .

51. In discrimination cases other than those involving race, the court may consider the plaintiff's membership in a protected class if the employer raises a BFOQ defense. See supra notes 39-43 and accompanying text.

52. Matsuda, supra note 2 , at $\mathbf{1 3 5 2 .}$

53. See, e.g., Fragante v. City of Honolulu, 699 F. Supp. 1429, 1431-32 (D. Haw. 1987) (District Judge Rosenblatt stated that "Fragante, in fact, has a difficult manner of pronunciation" and that he understood why the interviewers may have found Mr. Fragante's "[h]eavy Filipino accent ... difficult to understand."), aff'd, 888 F.2d 591 (9th Cir. 1989), cert. denied, 494 U.S. 1081 (1990). 


\section{Speech and Cultural Stereotypes}

Studies of speech evaluation show that we are particularly susceptible to received cultural stereotypes. For example, linguists using "Inatched guise" tests ${ }^{54}$ have found that a listener attaches cultural meanings to an accent which derive from the stereotypes and prejudices that the listener holds towards the race or ethnic group associated with that accent. ${ }^{55}$ Although we may behieve that certain accents are inherently more comprehensible or euphonious, our judgments stem from associations and cultural meanings imprinted on our unconscious ninds. ${ }^{56}$ An accent that one culture demigrates as low-class, vulgar, or rough may be esteeined as interesting or pretty in another. ${ }^{57}$

Such stereotyping also affects a listener's assessment of a speaker's intelligibility. Comprehension is as much a function of attitude as of variability. ${ }^{58}$ Research shows that language variability is inevitable and

54. Under the matched guise method, listeners hear tapes of the same words spoken by an actor using different accents. The listeners are not told that one person is acting out the different accents. They are then asked to evaluate what they assume are different speakers for qualities such as intelligence, confidence, trustworthiness, and warmth. The use of the same text and same speaker eliminates the role of personality traits or voice quality of the speaker in evaluation. The subjects are also tested separately to determine what racial stereotypes and prejudices they harbor.

Matsuda, supra note 2, at 1378 (footnote omitted).

55. See id.; J. Masterson et al., Components of Evaluative Reactions to Varieties of Irish Accents, 26 LANGUAGE \& SPEECH 215, 215-17 (1983). The authors point out that our judgments of accents are not rooted in aesthetics but are influenced by social judgments and "vocal stereotypes": " 'We like and dislike accents because of what they stand for, not for what they are." Id. at 216 (quoting Peter Trudgill, Accent, Dialect AND the SCHOOL 37 (1975)).

56. Regarding race discrimination, Professor Charles Lawrence has shown in his influential article, The Id, the Ego, and Equal Protection: Reckoning with Unconscious Racism, 39 STAN. L. REV. 317 (1987), that all of us in society have absorbed cultural messages of racial inferiority which pervade our seemingly neutral evaluation of others. He argues that racism is in large part a product of the unconscious; it is a set of beliefs whereby we irrationally attach siguificance to something called race. Id. at 322-23.

57. See generally Peter Trudgill, Accent, Dialect and the School (1975). Cf. Steven A. Holmes, U.S. Sues Company Over Language Firing; India-Born Credit Manager Had Accent, Houston CHRON., Jan. 18, 1992, at A7 (quoting Raj K. Gupta, an EEOC employee who wrote the EEOC's 1980 guidelines covering accent discrimination: "We have not seen any case of discrimination on the bases of accent involving any Western European immigrant. Generally, if an employer has an applicant who speaks with a French accent, they say, 'How cute,' or with an English accent, they say, 'How cute.' But if he speaks with a Hispanic accent they say, 'What's wrong with this guy?" ").

58. See, e.g., Peter Trudgill, ON Dialect 196 (1983) ("[C]laims for lack of mutual intelligibility are often exaggerated, are usually unsupported by research data and fail to acknowledge that it is normally much simpler and quicker to learn to understand a new variety than to learn to speak one."); ArtiTudes Towards LANGUAGE VARIATION (Ellen B. Ryan \& Howard Giles eds., 1982) (investigating the relationships between speech behaviors, language variation, and cognition). Listener behavior, as well as attitude, changes with a change in accent. John R. Edwards, Language Attitudes and Their Implications Among English Speakers, in ATTrTUDES Towards Language Variation supra at 20 . Prestigious or common accents often elicit greater responsiveness, attentiveness, and more cooperative behavior. See Howard Giles et al., Communication Length as a Behavioral Index of Accent Prejudice, 166 Linguistics 73, 74, 80 (1975). 
that moderate accent differences rarely impede communication when listeners are motivated and nonprejudiced..$^{59}$ But when listeners succumb to bias, their ability to assess and comprehend speech diminishes. This affects employment decisions ${ }^{60}$ and reinforces the acceptance of accent discrimination.

\section{Ready Acceptance of Accent Discrimination}

While Americans generally disavow race or gender discrimination, many accept accent discrimination as reasonable. Criticism of individuals based on their accents is commonplace and elicits few protests. ${ }^{61}$ For example, in 1988, the editors of the San Jose Mercury News recommended against voting for A.L. Hahn, a young Korean American who ran for city council in Santa Clara, California, despite their general agreement with Hahn on the issues. Among other reasons for withholding support, the editors stated that, although "[w]e like Hahn, . . . we think his heavy accent ... would make it difficult for him to be an effective councilman." 62 One could hardly imagine a responsible newspaper making the same statement about an African American woman and declaring that her skin color or sex would impede her success as a council member. Yet, because Mr. Hahn's accent was at issue and not another immutable trait, the San Jose Mercury News appeared comfortable in making and publishing this discriminatory statement.

By accepting such seemingly neutral observations with regard to

59. See Matsuda, supra note 2, at 1363 n.128 (citing Gass \& Varonis, The Effect of Familiarity on the Comprehensibility of Nonnative Speech, 34 LANGUAGE LEARNING 65 (1984)) (classifying four types of familiarity which improve comprehension of nonnative speakers: familiarity with topic familiarity with nonnative speech in general; familiarity with the particular, nonnative accent; and familiarity with the particular, nonnative speaker); see also sources cited supra note 58.

From personal experience and conversations with others, I know that motivated and nonprejudiced listeners can comprehend accented individuals without too much trouble. Because my parents speak with an accent, I find myself much more tolerant when conversing with accented individuals. I make an effort to listen to them, rather than turning them off and assuming that they cannot speak English or that I will be unable to understand them. Others who know or grew up around people with accents have told me of similar experiences. Comprehension depends on being tolerant and willing to listen, while putting aside assumptions about accented individuals.

60. See, e.g., Robert Hopper \& Frederick Williams, Speech Characteristics and Employability, 40 SPEECH MONOGRAPHS 296 (1973) (assessing employers' impressions regarding job competence based on speech samples); T.C. Jupp et al., Language and Disadvantage: The Hidden Process, in LANGUAGE AND SOCIAL IDENTITY 232 (John J. Gumperz ed. 1982) (discussing the impact of language differences on employment for South Asians in Great Britain); Rudolf Kalin \& Donald S. Rayko, Discrimination in Evaluative Judgments Against Foreign-Accented Job Candidates, 43 PSYCHOL. REP. 1203 (1978) (comparing listener reactions to.English-Canadian and other foreign accents); Roger W. Shuy, Language and Success: Who are the Judges?, in VARIETIES OF PRESENTDAY ENGLISH 303, 316 (Richard W. Bailey \& Jay L. Robinson eds., 1973).

61. As Charles Cairns, a professor of linguistics at Queens College and the City University of New York Graduate Center, states, "People still think that there is no problem with being intolerant over the way other people speak .... They feel that it's acceptable to criticize or discriminate against people with nonstandard ways of speaking English." Hernandez, supra note 8, at A12.

62. For Santa Clara Council, SAN Jose Mercury News, Oct. 18, 1988, at 6B. 
accent, one overlooks the damaging impact such discrimination has on accented individuals. Even though immigration continually changes the ethnic composition of the United States, accents are still an impediment, even a stigina, for those in schools, workplaces, and social settings. Because their Enghish does not conform to the accepted norm, accented individuals are frequently subjected to off-color remarks, gibes, and ridicule, causing feelings of anger, insecurity, and shame. For example, Galo Conde, a New York City public school teacher who arrived in the United States from Colombia twenty years ago, says that others, including his students, have often snubbed him because of his accent. He says that "[s]ometimes native Americans act like they have never heard a person with an accent." 63 Carmen Friedman, another Colombian immigrant, took classes to eliminate her accent after realizing it had not dimimished during her five years in the United States. Although she could communicate effectively in Enghish, she did not "want to feel uncomfortable every time [she] sa[id] something," or have her "accent hurt [her] self-esteein anyinore." $" 64$

Bias against accents also manifests itself in the employment context. As with criticism of accents in other contexts, accent-based discrimination in the employment arena is accepted where discrimination based on race and gender is condemned. In one instance, a Dominican woman from Queens enrolled in accent-elimination classes after her managers complained, in otherwise positive job reviews, that they could not understand her because of her accent. The woman, a 48-year-old senior accountant, suspects that the criticism was a pretext to keep her from being promoted: she had received no such criticism previously in her twenty years with the employer, and a speech evaluation clinic found her speech easy to understand..$^{65}$

Stories such as those of this 48-year-old semior accountant or Galo Conde or Carmen Friedman are not uncommon. Like them, many immigrants fear that if they do not speak like native-born Americans, they will be unable to obtam employment or promotions. For exainple, Shaiao Moore, a Taiwan native, is convinced that her job advancement at Eastern Airlines depends on her improving her pronunciation, although her command of English is excellent. ${ }^{66}$ Maria Delgado tells the same story, stating that "[i]f they don't happen to need a Hispanic or bilingual person, they don't hire me. They hire the American. Well, I'm American, too! I think it would help if my accent was not so obvious."

63. Hernandez, supra note 8 , at $\mathbf{A} 12$.

64. Id.

65. Id.

66. Landers, supra note 9 , at $1 \mathrm{~B}$.

67. Id. See also Solomon, supra note 9, and Wilkinson, supra note 9, for other stories of immigrants trying to reduce or eliminate their accents in order to advance in the work force or gain acceptance. 
Finally, the acceptance of accent discrimination also pervades our legal system. For example, in Sirajullah v. Illinois State Medical Inter-Insurance Exchange, ${ }^{68}$ an accent discrimination case brought under $\S 1981$ of the Civil Rights Act of $1964,{ }^{69}$ the defendants had denied medical malpractice insurance to Dr. Sirajullah, a Bangladeshiborn orthopedic surgeon. The insurer stated that its denial was in part due to its belief that Dr. Sirajullah's accent would impede his communication witl patients and jurors, making him more susceptible to malpractice liability. The defendants noted that they often rejected doctors because of their accents. The court accepted this argument:

Accent is relevant where, as here, the ability to communicate is at issue. . . . There is no evidence that the ability to communicate effectively in English is not a reasonably necessary prerequisite either to a successful medical practice or to the ability to defend a lawsuit. Therefore, it was not unreasonable for the defendants to rely on the effect of Sirajullah's English language disability as one of the reasons for denying his application.... Significantly, as of July 1,1986 , the defendants rejected 19 otler applicants of varying races and nationalities in part because they lad foreign accents that prevented them from communicating effectively. Under these circumstances, Sirajullah cannot say that the defendants treated him differently than similarly situated applicants. ${ }^{70}$

The court's empliasis on accent as a reasonable basis for discrimination illustrates the widely lield belief that accent discrimination is legitimate.

\section{Customer Preference}

Bias against accented individuals and the ready acceptance of accent discrimination also lead to wider judicial acceptance of the customer preference defense in accent discrimination cases. Courts in accent cases regularly approve customer preference defenses even thougli they liave consistently rejected them in other types of title VII suits. ${ }^{71}$

Early in the listory of title VII, employers frequently justified employment decisions by the need to keep customers satisfied. A restaurant owner might tell a court that lie would love to lire an African American waitress, but his customers would refuse service from her. An airline might argue that it had to hire women as fiight attendants because

68. No. 86 C 8668, 1989 WL 88316 (N.D. Ill. Aug. 1, 1989).

69. 42 U.S.C. $\S 1981$ (1988). Section 1981 prohibits discrimination in the formation and enforcement of contracts based solely on ancestry or genetically distinct characteristics. Saint Francis College v. Al-Khazraji, 481 U.S. 604, 613 (1987).

70. Sirajullah, No. 86 C 8668,1989 WL 88316 , at *3 (citations omitted).

71. Under EEOC regulations regarding gender discrimination, customer preference is a $B F O Q$ only where discriminatory hiring is necessary for authenticity or genuineness, as in the case of actors or actresses. 29 C.F.R. § 1604.2(a)(2) (1992). 
women are more naturally maternal and soothing to air travelers. ${ }^{72}$

Courts rejected these arguments, holding that they were based on assumptions not tolerated under title VII. The core purpose of title VII is to ensure that considerations of ability govern employment decisions, not racist or sexist assumptions. ${ }^{73}$ Iromically, once employers instituted nondiscriminatory practices, many employers found that they had misjudged the strength of customer preferences in the first place: airline passengers accepted male flight attendants, and white patrons conducted business with African American employees. The requirements of title VII thus "help[ed] move us away from the sorry cycle of stereotype himiting opportunity, and limited opportumity reinforcmg stereotype."74 Moreover, title VII forbids discrimination even where employers can prove that they will lose customers. ${ }^{75}$ This uniform, nondiscrimmation standard disallows an economic advantage to those employers who would otherwise accede to the bigoted demands of customers.

But when it comes to accent discrimination cases, the courts currently accept defenses with a disconcertingly familiar ring: "We have nothing against iminigrants. We sinnply can't have someone with an accent doing this job. Our customers won't be able to understand her."76

In many jobs, of course, successful job performance will depend on the employee's abihty to speak with a certam level of intelligibility. Nevertheless, the claim that custoiners will not conduct business with accented employees raises two problems. First, employers often make

72. In Diaz v. Pan Am. World Airways, 442 F.2d 385 (5th Cir.), cert. denied, 404 U.S. 950 (1971), an airline rejected a male applicant for a flight attendant position because the airline did not hire men for the job; the airline thought women were better at the "non-mechanical aspects of the job," such as serving and reassuring anxious passengers. Id. at 385-87. Gender, the airline argued, was therefore a BFOQ. The Fifth Circuit disagreed on the ground that such customer preference reflected the "very prejudices [Title VII] was meant to overcome." Id. at 389.

73. See Price Waterhouse v. Hopkins, 490 U.S. 228, 243 (1989) ("The intent to drive employers to focus on qualifications rather than on race, religion, sex, or national origin is the theme of a good deal of the statute's legislative history.").

74. Matsuda, supra note 2, at 1378.

75. Rucker v. Higher Educ. Aid Bd., 669 F.2d 1179, 1181 (7th Cir. 1982) ("[I]t is clearly forbidden by Title VII[] to refuse on racial grounds to hire someone because your customers or clientele do not like his race."); Fernandez v. Wynn Oil Co., 653 F.2d 1273, 1276-77 (9th Cir. 1981) (rejecting gender as a BFOQ where an employer asserted that South American clients would have difficulty conducting business with a female Vice President of International Operations).

76. Fragante v. City of Honolulu, 669 F. Supp. 1429, 1431-32 (D. Haw. 1987), aff'd, 888 F.2d 591 (9th Cir. 1989), cert. denied, 494 U.S. 1081 (1990), is one example:

The job [as a DMV clerk] is a difficult one because it involves dealing with a great number of disgruntled members of the public. ... Fragante was bypassed because of his 'accent.' ... While Plaintiff has extensive verbal communication skill in English it is understandable why the interviewers might reach their conclusion. And while there is no necessary relationship between accent and verbal communication . . . listeners stop listening to Filipino accents, resulting in a breakdown of communication.

See also Mandhare v. W.S. LaFargue Elem. Sch., 605 F. Supp. 238, 239 (E.D. La. 1985) (accepting defendant's rationale for refusing to rehire plaintiff-librarian on grounds that her heavy accent and speech patterns would impede her ability to communicate with primary school students), rev'd without op., 788 F.2d 1563 (5th Cir.), and cert. denied, 479 U.S. 931 (1986). 
such claims without any empirical foundation, incorrectly assuming the inability of customers to comprehend certain accents. Given the linguistic evidence that comprehension adjustments are relatively easy for motivated listeners, ${ }^{77}$ claims of customer preference should be supported at least by some evidence of the applicant's lack of intelligibility. The second problem is actual prejudice. An employer may associate an accent witl negative traits, sucl as laziness or lack of intelligence, because the employer loolds negative stereotypes and prejudices against a particular race or ethnic group. ${ }^{78}$ By accepting the custoiner preference defense without close scrutimy, the courts fail to determine whether customers actually have such preferences, whether customer preference is a relevant consideration under title VII wlien the plaimtiff is sufficiently intelligible for the position at issue, and whether the defense is a pretext for prejudice against accented individuals.

\section{Examples of Accent Discrimination Cases}

1. Fragante v. City \& County of Honolulu ${ }^{79}$

Manuel Fragante, then a sixty-year-old Filipino immigrant, applied for an entry-level Civil Service Clerk job at the City of Honolulu's Division of Motor Vehicles and Licensing (DMV). The position involved constant public contact, as well as clerical tasks. Mr. Fragante scored the highest of 721 test takers on the written Civil Service Examination, whicli tested word usage, grammar, and spelling. He was ranked first on a certified list of ehigible candidates for two clerical positions. $^{80}$

Two DMV employees, the assistant licensing administrator and the division secretary, then interviewed Mr. Fragante. ${ }^{81}$ The interview consisted of a ten to fifteen minute conversation. The interviewers had no list of standard questions, but rather a "rating sheet" one of the interviewers had devised, which an expert in einployinent practices would later call the "worst" he had seen in his thirty-five years of experience in the field. ${ }^{82}$ Both interviewers reported difficulty in understanding Mr. Fragante because of his Filipino accent and determined that DMV patrons would have similar difficulty wlien speaking to $\mathrm{Mr}$. Fragante over the telephone or at the information counter. ${ }^{83}$ Due to their judgment that Mr. Fragante's accent would interfere with his job perform-

77. See supra notes 58-59 and accompanying text.

78. See supra notes $54-57$ and accompanying text.

79. 888 F.2d 591 (9th Cir. 1989), cert. denied, 494 U.S. 1081 (1990).

80. Id. at 593 .

81. Id.

82. Matsuda, supra note 2, at 1337 . The expert noted that the rating scale was not correlated to any explicit evaluation of ability, and the sheet listed "oddly matched" categories, such as "inarticulate" in opposition to "convincing." Id.

83. Fragante, 888 F.2d at 593-94. 
ance, the interviewers gave him a negative recommendation. Mr. Fragante dropped from the top of the hist of eligible candidates and was not offered the DMV job. ${ }^{84}$

The district court uplield the employment decision, observing that: The job is a difficult one because it involves dealing witl a great number of disgruntled members of the public. The clerk must deal witl $200-500$ people per day, many of whom are angry or complaining and who do not want to hear what the clerk may have to explain concerning their applications or in answer to their questions. ${ }^{85}$

The district court's remarks appear to condone the idea that anticipated customer preference may dictate whether an accented individual is hired. The court emphasized not whetler Mr. Fragante was intelligible, ${ }^{86}$ but rather the intolerance of "disgruntled members of the public" and their unwillingness to deal with an accented individual. ${ }^{87}$ The Ninth Circuit accepted the district court's approach, noting the trial court's observation that "Fragante, in fact, lias a difficult manner of pronunciation." 88 Relying on this statement, the Ninth Circuit affirmed the district court's decision on the ground that Mr. Fragante was passed over because of the "deleterious effect of his Filipino accent on his ability to communicate orally, not merely because he had such an accent." 89

The problem in the opinions of the district court and the Ninth Circuit is that both courts deferred to the subjective assessments of the interviewers who spoke to Mr. Fragante. These interviewers had no formal training in interviewing, and they used rating sheets that were "vague," "inadequate," and "not clearly job related nor well defined."90 The district court also relied on its own subjective assessment to determine, after listening to him in court, that Mr. Fragante "has a difficult manner of pronunciation." 91 The courts had no objective method of evaluating Mr. Fragante's accent or its impact on listeners. They found

\footnotetext{
84. Id. at 594.

85. Fragante v. City of Honolulu, 699 F. Supp. 1429, 1431 (D. Haw. 1987), aff'd, 888 F.2d 591 (9th Cir. 1989), cert. denied, 494 U.S. 1081 (1990).

86. At trial, a linguist explained that Mr. Fragante speaks grammatically correct standard English, with a characteristic Filipino accent. He further testified that the degree of phonological deviation in Mr. Fragante's speech was not so different from other Hawaiians that he would not be understood. Matsuda, supra note 2, at 1337. For a detailed discussion of Mr. Fragante's case, see id. at $1333-40$.

87. See Fragante, 699 F. Supp. at 1431. Such deference to customer preference is not evident when courts are adjudicating claims of race or gender discrimination. See supra notes $71-75$ and accompanying text.

88. Fragante, 888 F.2d at 598.

89. Id. at 599.

90. Fragante, $699 \mathrm{~F}$. Supp. at 1430 . An industrial psychologist testified that the interview and the rating system were "entirely subjective and did not meet federal or any acceptable standards of collective decisionmaking." Id.
}

91. Id. at 1432 . 
his accent deleterious to his ability to commumicate without any empirical evidence that customers would not understand him. ${ }^{92}$ Moreover, the courts' reliance on subjective assessments posed the real danger that prejudice, whether conscious or unconscious, may have entered into the evaluation of Mr. Fragante's accent.

\section{Hou v. Pennsylvania Department of Education ${ }^{93}$}

Dr. Roger Hou, a Chimese-born mathematician, sued Slippery Rock State College under title VII, alleging that he was denied a promotion from associate professor to full professor on grounds of discrimination against his national origin, race, and religion. ${ }^{94}$ Slippery Rock's promotions pohicy for professors required that the candidate achieve an "Excellent" rating in four categories: (1) teaching effectiveness, (2) mastery of subject matter, (3) continuing scholarly growth, and (4) contributions to the college. ${ }^{95}$ The college measured the most important criterion-teaching effectiveness-by student evaluations, the quality of the candidate's course syllabi, reports of classroom visits by peers, and evaluations of the department chair. ${ }^{96}$

Dr. Hou, pointing to several negative recommendations pertaining to his accent, contended that the criticisms of his teaching ability were a pretext for discrimmation. ${ }^{97}$ The district court found these criticisms legitimate because teaching effectiveness in part depends on the ability to commumicate the subject matter to students. ${ }^{98}$ However, the court also recognized that " $[t]$ he issue of accent in a foreign-born person of another race is a concededly delicate subject when it becomes part of peer or student evaluations, since many people are prejudiced against those with accents." 99 At least one peer evaluation supported the court's concern:

$\mathrm{He}$ is at a decided disadvantage in the classroom because of his natural accent. That is, he tends to speak too rapidly at times and his students often use this factor coupled with his repeated use of standard, clipped phrases such as "you see what I mean" and "I mean" as excuses to lose interest in the discussions. ... [F]or the more serious students [Dr. Hou's grammatical errors] do not

92. The Ninth Circuit noted that the interviewers had recorded their negative evaluations of Mr. Fragante's accent on their rating sheets. It then concluded that, "[a]s such, a legitimate factual basis for this conciusion that Fragante would be less able than his competition to perform the required duties was established." Fragante, 888 F.2d at 598. Note, however, that this "legitimate factual basis" was established by the subjective assessments of two untrained interviewers.

93. 573 F. Supp. 1539 (W.D. Pa. 1983).

94. Id. at 1540-41.

95. Id. at 1541-42.

96. Id. at 1542 .

97. Id. at 1547 .

98. Id.

99. Id. 
prove to be obstacles to learning. ${ }^{100}$

The comments of both the court and evaluator highlight the potential for prejudice or other impermissible factors creeping imto subjective assessments of a foreign-born person's accent. Dr. Hou's accent may very well have harmed his teaching and communication abilities, but the Hou court nevertheless rehed on subjective assessments in its decision, despite its awareness of the inherent possibility of prejudice in such opmions. Moreover, the court failed to address squarely whether improper considerations may have in part determined Dr. Hou's opportunity for a promotion.

II

\section{ADDING AN OBJECTIVE ELEMENT TO ACCENT Discrimination CASES}

While estabhishing qualifications for job positions is an employer's prerogative, the use of subjective standards to evaluate accents carries the danger of being colored by unlawful bias. Those who wish to pursue accent discrimination claims have no recourse when courts defer to such assessments as reasonable instead of scrutmizing them closely, as they would in race or gender discrimination cases. ${ }^{101}$ This Comment argues that introducing an objective element into the assessment of accents would advance Title VII's goal of compelling employers to focus on specific, job-related qualifications, rather than on discriminatory criteria, in making personnel decisions. ${ }^{102}$

\section{A. Dangers of Subjective Criteria}

There are two basic scenarios in which an employer utilizes subjective standards in making hirmg or promoting decisions. The first entails employer delegation of decision-making authority to lower management without specific instructions for its exercise. For example, the employer may instruct a supervisor to select the "best worker" for promotion. In the absence of specific, reviewable promotion criteria, the employee who chooses to challenge a denial of promotion will be disadvantaged in trying to prove discrimination. She inay not even know whether her accent or some other trait influenced the supervisor's decision. "Undetected disparate treatment is rendered more probable if an employer is permitted to explain a decision by reference to a generality such as 'the best candidate' ...."103

The second scenario entails an employer's use of inherently subjec-

100. Id.

101. See supra notes $71-78$ and accompanying text.

102. See supra text accompanying notes 21,73 .

103. Paul N. Cox, The Future of the Disparate Impact Theory of Employment Discrimination After Watson v. Fort Worth Bank, 1988 B.Y.U. L. REv. 753, 766. 
tive criteria that require discretionary judgment in application. Such criteria include, for example, the elusive qualities of "articulateness" or "intelligibility" and are commonly thought to provide a reasonable basis for evaluation. Exphicit examples of accent discrimination tend to fit this scenario. Though few would deny the sigmificance of qualities such as good verbal skills in the employment context, reduction of those qualities to abstract concepts is difficult or meaningless without extrinsic, concrete standards. Subjective criteria, lacking in specific content, merely require the histener to agree to a certain characterization of the speaker's accent. Thus, when an employer asserts the "unintelligible English" defense, the employer simply asks the court to agree that the employer's characterization of the plaintiff's accent is roughly accurate. In other words, the court, too, must judge the plaintiff's accent subjectively, providing another opportunity for prejudice to intrude. ${ }^{104}$

By contrast, courts condemn employers who base employment decisions on wholly subjective criteria without any restraint on discretion in the context of racial discrimination. For example, the court in Rowe v. General Motors Corp. ${ }^{105}$ criticized white foremen's subjective evaluations of African American employees' abilities, merits, and capacities in determining whether to promote or transfer employees from hourly to salaried positions. ${ }^{106}$ The court found that General Motors' promotion and transfer procedures violated title VII because the company failed to instruct the foremen as to the qualifications required for advancement; the standards as applied were vague and subjective and lacked safeguards against discrimmation. ${ }^{107}$

Similarly, the court in Crawford v. Western Electric Co. ${ }^{108}$ found Western Electric's "skill" requirement highly suspect because of its disparate impact on African Americans, whose advancement rates were significantly slower than those of white employees. ${ }^{109}$ The evaluation procedures were deficient because supervisors lacked written guidelines for employee ratings, kept no permanent records of the quality and efficiency of each employee's work, did not record reasons for giving ratings below the highest, and failed to demonstrate the use of standardized criteria in making their evaluations. ${ }^{110}$

Finally, in Baxter v. Savannah Sugar Refining Corp., ${ }^{111}$ the court

104. See id. at 767 .

105. 457 F.2d 348 (5th Cir. 1972).

106. Id. at $353,358-59$.

107. Id. at 358-59.

108. 614 F.2d 1300 (5th Cir. 1980).

109. Id. at 1313, 1315.

110. Id. at 1314. The court, citing Rowe, held that "[e]stablishing qualifications is an employer's prerogative, ... but an employer may not utilize wholly subjective standards by which to judge its employees' qualifications and then plead lack of qualification when its promotion process, for example, is challenged as discriminatory." Id. at 1315 (citation omitted).

111. 495 F.2d 437 (5th Cir.), cert. denied, 419 U.S. 1033 (1974). 
held the defendant's promotion practices, which kept African American employees confined to lower-paying, less-skilled positions, illegal under title VII. ${ }^{112}$ The defendant conferred promotions, without giving notice of job openings, based on supervisors' recommendations. ${ }^{113}$ Moreover, the defendant employer gave no objective guidelines to supervisors, who were almost all white, as to the appropriate qualifications for promotion. ${ }^{114}$ The African American employees, without notice of openings or necessary qualifications, were completely dependent upon their white supervisors for advancement. ${ }^{115}$

In these and other race discrimination cases, ${ }^{116}$ courts have recognized the danger of prejudice that inlieres when those with decision-making authority assess employees of another racial group in the absence of objective criteria. The courts emphasized the supervisors' suspect methods of evaluation and their disparate impact on African Americans, acknowledging "the impropriety [under title VII] of a promotional system dependent upon supervisory recommendations uncontrolled by clearly delineated and objective job criteria." 117

Courts are, however, quite permissive in their review of nonaccented supervisors' subjective assessinents of accented employees and job applicants. Recall that in Fragante the district court acknowledged defects in the interviewing process but nevertheless sustained the interviewers' decision that Mr. Fragante's accent would impede his job performance, ${ }^{118}$ finding that the rating system was not discriminatory. ${ }^{119}$ The court, however, never questioned the subjectivity of the assessments. Moreover, both the district court and the Ninth Circuit ignored the very real possibility of speech and cultural stereotypes intruding into employment decisions in sucli situations.

This permissive approach to accent discrimination cases clashes

112. Id. at 440,442 .

113. Id. at 441 .

114. Id.

115. Id.

116. See, e.g., Miles v. M.N.C. Corp., 750 F.2d 867, 871 (11th Cir. 1985) (recognizing that "subjective evaluations involving white supervisors provide a ready mechanism for racial discrimination"); Swint v. Pullman-Standard, 539 F.2d 77, 105 n.72 (5th Cir. 1976) (noting that the use of subjective promotion criteria by foremen, most of whom were white, has potential for racial discrimination); Cypress v. Newport News Gen. \& Nonsectarian Hosp. Ass'n, 375 F.2d 648, 655 (4th Cir. 1967) (condemning a process whereby African American physicians depended on the approval of a three-fourths majority of an all-white group of physicians for admission to staff membership at a private hospital); Verdell v. Wilson, 602 F. Supp. 1427, 1439 (E.D.N.Y. 1985) (noting that a subjective evaluation system must be scrutinized for abuse and that the "potential for abuse is heightened where the evaluator is white").

117. Baxter, 495 F.2d at 441 n.3.

118. See Fragante v. City of Honolulu, 699 F. Supp. 1429, 1430-31 (D. Haw. 1987), (noting that the rating sheets used by the interviewers were "inadequate," "vague," and "not clearly job related nor well defined"), aff'd, 888 F.2d 591 (9th Cir. 1989), cert. denied, 494 U.S. 1081 (1990).

119. Id. at 1432 . 
with the close scrutiny courts give to subjective evaluations in the context of racial discrimination because of their inherent potential for prejudice. Compounding the subjectivity problem is the courts' own lack of objective means for determining intelligibility. Like many employers, courts rely on their own subjective assessinents in accent discrimination cases, making possible the intrusion of cultural and speech stereotypes upon their judgment.

\section{B. A Call for Objectivity and the Test of Spoken English}

Cognizant of the dangers inherent in subjective evaluations of accent, this Comment argues that courts should shift to objective methods of evaluation. This Comment takes as the starting point for its proposal the recominendations of Professor Matsuda, who suggests that courts should consider four questions when adjudicating accent discrimination cases:

1. What level of communication is required for the job?

2. Was the candidate's speech fairly evaluated?

3. Is the candidate intelligible to the pool of relevant, nonprejudiced listeners, such that job performance is not unreasonably impeded?

4. What accommodations are reasonable given the job and any limitations in intelligibility? ${ }^{120}$

Professor Matsuda's questions increase the objectivity of courts' assessment of a plaintiff's claim by limiting judicial inquiry into an accented plaintiff's suitability for einployment to factors specifically related to job performance and requirements.

Professor Matsuda's suggested inquiries do not, however, provide a coinplete solution to the subjectivity problein. Thus, under Professor Matsuda's first criterion, courts may find that an individual's accent will not impede her performance only in those jobs that do not require public contact or demand extensive verbal coinmunication with co-workers or other business persons (for example, data entry clerks, assembly line workers, custodians). Accented individuals will then be relegated to lower-paying jobs with less opportunity for advancement than positions for which they might otherwise be legitimately qualified. Professor Matsuda's fourth question, suggesting a requirement of reasonable accommodations, could be unduly burdensome to einployers. ${ }^{121}$ If a pro-

120. Matsuda, supra note 2, at 1368; see also Carolyn R. Matthews, Comment, Accent: Legitimate Nondiscriminatory Reason or Permission to Discriminate?, 23 AR1z. ST. L.J. 231, 256 (1991) (recommending that courts not defer to employers, but instead consider "(1) what level of communicative ability the job requires, and (2) whether the employer made a valid determination of whether the applicant or employee met the qualifications").

121. Professor Matsuda suggests reasonable accommodations within the context of her larger proposal that the Americans with Disabilities Act (ADA) be applied in accent discrimination cases. 
spective employee cannot communicate at an acceptable level, forcing the employer to hire her may very well contravene the spirit and intent of title VII by diminishing the legitimate right of an einployer to hire and promote qualified individuals. ${ }^{122}$

Finally, Professor Matsuda recommends that courts be critical in reviewing an employer's evaluation of a plaintiff's accent. In keeping with this recommendation, this Comment proposes that courts utilize the Test of Spoken Enghish as a tool in the adjudication of accent discrimmation cases. The Test of Spoken English is a standardized test that evaluates the spoken English proficiency and comprehensibility of people whose native language is not English and sets up clear guidelines by which to judge comprehensibility. Enploying this test, courts can define intelligibility in objective terms, rather than simply ratifying predilections for nonaccented English.

\section{The Test of Spoken English}

The Educational Testing Service (ETS) ${ }^{123}$ developed the Test of Spoken English (TSE) in order to provide a reliable measure of proficiency in spoken English, affording educational institutions, governinent agencies, and other organizations an objective means of assessing the linguistic ability of nonnative speakers of English. Academic institutions currently use TSE scores to evaluate the spoken English of applicants for teaching assistantships or other academic positions, ${ }^{124}$ while various professional licensing agencies use the scores for selection and certification purposes. ${ }^{125}$

Thus, she proposes that an accent be treated as a handicap under law. See Matsuda, supra note 2, at 1379-82, 1379 n.179.

I am, however, discomforted by the idea that accent, a trait reflective of national origin and many other personal characteristics, be considered a "handicap." See id. at 1329. Logically extended, this view could apply to other immutable traits, such as race or gender. While one may suffer discrimination and disadvantage in American society on account of oue's race, gender, or national origin, I am unwilling to counter such discrimination by acceding to the view that minority characteristics or status constitutes protected "disabilities" simply to "use" the ADA.

122. See supra notes $15-17$ and accompanying text.

123. Educational Testing Service administers the Test of English as a Foreign Language (TOEFL), the Test of Written English (TWE), and the Test of Spoken English (TSE) under the general direction of a policy council that was established by, and is affiliated with, the College Board and the Graduate Record Examinations Board. See Educational Testing Serv., 1992-93 BULLETIN OF INFORMATION FOR TOEFL/TWE AND TSE 2 (1992) [hereinafter ETS BuLlETIN] (on file with author). Inquiries can be directed to P.O. Box 6151, Princeton, NJ 08541-6151.

124. For example, the University of California at Berkeley requires all first-time Graduate Student Instructors from countries whose official language is not English to take either the TSE or the Speaking Proficiency English Assessment Kit (SPEAK), which consists of retired TSE test forms. Interview with Marilyn Seid-Rabinow, International Graduate Students Instructor and English Oral Proficiency Testing Coordinator, College Writing Program, University of California at Berkeley, in Berkeley, CA (Mar. 1, 1993) (notes and materials on file with the author).

125. ETS BulletiN, supra note 123, at 4 .

There are two separate registration categories for the TSE: TSE-A and TSE-P. TSE-A is for 


\section{Purpose and Composition of the Test of Spoken English}

The TSE provides an objective evaluation of the spoken English of those who have learned English as a second language, regardless of their native language. ${ }^{26}$ Although the test is not targeted to any specialized language usage, its value as a predictor of language skills in the employment context has been proven in a variety of communication-intensive jobs. ${ }^{127}$

The TSE, which takes twenty to thirty minutes to complete, requires exammees to answer orally a variety of written and recorded questions. ${ }^{128}$ The examinee speaks into a microphone, and her answers are recorded. ${ }^{129}$ No writing is required. ${ }^{130}$ The examinee is asked to: (1) answer questions about herself (Section 1); ${ }^{131}$ read a printed passage aloud (Section 2); ${ }^{132}$ complete partial sentences (Section 3 ); ${ }^{133}$ tell a story about a series of pictures (Section 4); ${ }^{134}$ answer questions about a single picture (Section 5); ${ }^{135}$ answer questions about general topics (Section

teaching and research assistant applicants, as well as for other undergraduate or graduate school applicants. TSE-P is for all other individuals, including those seeking professional or occupational licensing or certification. Id.

126. See infra notes $139-43$ and accompanying text.

127. Educational Testing Serv., Test of Spoken English Manual for Score Users 24 (4th ed. 1992) [hereinafter ETS MANUAL] (on file with author). The ETS MANUAL can be obtained from: TOEFL/TSE Services, P.O. Box 6151, Princeton, N.J. 08541-6151. The ETS cautions that the "validity [of the TSE] for specific job-related uses should be established before decisions affecting individuals are made on the basis of TSE scores." Id. Nevertheless, the success of the TSE in a range of professions supports its use in the fashion advoeated by this Comment. See infra notes 149-56 and accompanying text.

128. ETS BULLETIN, supra note 123 , at 4.

129. Id. at 22 .

130. Id. at 4 .

131. The examinee has 15 seconds to answer eaeh question. ETS lists the following sample questions:

1. What is your registration number?

2. How long have you been studying English?

3. Why are you taking this test?

Id. at 23 .

132. In this section, the examinee has one minute to read a printed paragraph silently to herself. She then reads the paragraph aloud. Id.

133. Section 3 gives a set of 10 partial sentences, which the examinee must complete. Examples include:

1. Whenever John comes home...

2. Before we left for class...

3. Because the restaurant is closed...

Id. The partial sentences are printed. The examinee hears only the number of each question and has 10 seconds to respond. Id.

134. The examinee has one minute to study the pictures, which tell a continuous story, and one minute to relate the story. Id.

135. The examinee has 30 seconds to study the picture and is aslied four questions about it. The questions are not printed. The examinee has approximately 12 seconds to respond to each. Sample questions include:

1. Where is this scene taking place?

2. What has just happened?

3. What will the boy probably do after this? 
6); ${ }^{136}$ and give a short presentation as if speaking to a group of students or colleagues (Section 7). ${ }^{137}$ This format "retains the high degree of validity inherent in the direct interview procedure while virtually eliminating the subjective measurement problems associated with interviewing."138

\section{TSE Scores and Their Meaning}

ETS designed its scoring methods to maximize objectivity. ${ }^{139}$ Two raters evaluate each tape, both of whom are experienced teachers and specialists in Enghish, Enghish as a second language, or linguistics. ${ }^{140}$ Neither rater knows the scores that the other assigns. ${ }^{141}$ A third rater evaluates the examinee's tapes whenever there is a significant discrepancy in the overall comprehensibility scores that the first two raters assigned. ${ }^{142}$ ETS trains all raters in scoring TSE examinations and retrains them when score discrepancies indicate such a necessity. To ensure consistent use of scoring guidelines, raters review old answer tapes prior to each rating session. ${ }^{143}$

The raters give scores in four categories: (1) overall comprehensibilId.

4. How could this situation have been avoided?

136. The examinee gives her opinions on "topics of general interest." Her answers are evaluated for the quality of expression, not for the content of the ideas. The questions are not printed. The examinee is given 15 seconds to prepare her answer and approximately 45 seconds to respond. Examples include:

1. Describe the things that make a perfect day.

2. Describe a telephone in detail.

3. The number of automobiles being manufactured in the world increases yearly. As a consequence, air pollution has also increased. How do you think the problem of Id. automobile pollution should be handled?

137. The examinee is given a schedule or notice describing the activities of a club, conference, class, or similar function. The examinee has one minnte to study the schedule or notice and one minute to give her presentation as if she were speaking before a group.

ETS provides an example of a schedule of the quarterly meeting of the Mountainville Nature Club. The examinee is asked to imagine that she is the club president speaking to the club members about the schedule. Id.

138. ETS MANUAL, supra note 127 , at 7.

139. To ensure the objective grading of the TSE, the ETS staff trains raters on the use of the TSE scoring key. The first part of each workshop is devoted to scoring actual TSE examinations, arranged from low score to high score. In group sessions with the TSE staff, raters then discuss appropriate scores until all discrepancies are resolved. Potential raters then score TSE examinations that have been randomly arranged. Based on the scores assigned from the previously graded batch, the TSE staff determines which raters have mastered the rating procedure and are ready to score actual TSE answer tapes. Retraining is required of experienced raters when their scoring indicates unacceptable discrepancies. $I d$. at 12.

140. Id.

141. Id.

142. Id. See infra text accompanying notes $144-48$ for a discussion of the different scoring categories, including the overall comprehensibility category.

143. ETS MANUAL, supra note 127, at 12. 
ity, (2) pronunciation, (3) grammar, and (4) fluency. ${ }^{144}$ The raters score each category independently, and the final score in each category represents the average of the raters' scores. ${ }^{145}$ Scores for pronunciation, grammar, and fluency range from 0 to 3 , rounded to the nearest tenth. ${ }^{146}$ The overall comprehensibility score ranges from 0 to 300 , rounded to the nearest decade. ${ }^{147}$ ETS provides guidelines for interpreting the scores in relation to coinprehensibihity. ${ }^{148}$

144. ETS BULLETIN, supra note 123 , at 27.

145. ETS MANUAL, supra note 127 , at 12.

146. ETS interprets the scores according to the following descriptions:

Pronunciation

0.0-0.4 Frequent phonemic errors and foreign stress and intonation patterns that cause the speaker to be unintelligible.

0.5-1.4 Frequent phonemic errors and foreign stress and intonation patterns that cause the speaker to be occasionally unintelligible.

1.5-2.4 Some consistent phonemic errors and foreign stress and intonation patterns, but speaker is intelligible.

2.5-3.0 Occasional nonnative pronunciation errors, but speaker is always intelligible.

Grammar

0.0-0.4 Virtually no grammatical or syntactical control except in simple stock phrases.

0.5-1.4 Some control of basic grammatical constructions but with major and/or repeated errors that interfere with intelligibility.

1.5-2.4 Generally good control in all constructions, with grammatical errors that do not interfere with overall intelligibility.

2.5-3.0 Sporadic minor grammatical errors that could be made inadvertently by native speakers.

Fluency

0.0-0.4 Speech is so halting and fragmentary or has such a nonnative flow that intelligibility is virtually impossible.

0.5-1.4 Numerous nonnative pauses and/or a nonnative flow that interferes with intelligibility.

1.5-2.4 Some nonnative pauses but with a more nearly native flow so that the pauses do not interfere with intelligibility.

Id.

2.5-3.0 Speech is smooth and effortless, closely approximating that of a native speaker.

147. Id.

148. ETS describes the score ranges for overall comprehensibility as follows:

0-90 Overall comprehensibility too low in even the simplest type of speech.

100-140 Generally not comprehensible due to frequent pauses and/or rephrasing, pronunciation errors, limited grasp of vocabulary, and lack of grammatical control.

150-190 Generally comprehensible but with frequent errors in pronunciation, grammar, choice of vocabulary items, and with some pauses or rephrasing.

200-240 Generally comprehensible with some errors in pronunciation, grammar, choice of vocabulary items, or with pauses or occasional rephrasing.

250-300 Completely comprehensible in normal speech, with occasional grammatical or pronunciation errors in very colloquial phrases.

Id.

At the University of California at Berkeley, foreign graduate student instructors are requircd to score 220 or above on the SPEAK (i.e., retired versions of the TSE) in overall comprehensibility before they are allowed to teach. SPEAK tests are graded either by ETS raters or UC Berkeley graders trained by ETS. Interview with Marilyn Seid-Rabinow, supra note 124. 


\section{Validity of the Test of Spoken English}

Although there is no single inethod for validating einployinent tests as predictors of job performance, ${ }^{149}$ EEOC Guidelines recognize three basic methods of validation that the American Psychiatric Association has developed. ${ }^{150}$ The first, "einpirical" or "criterion-related" validity, correlates test scores with objective measures or criteria of successful job performance. The second, "construct" validity, correlates test scores with certain identifiable characteristics that are important to job performance. The third, "content" validity, assesses whether the test closely approximates tasks to be performed on the job. ${ }^{151}$

Since the issue in accent discrinination cases is whether a plaintiff is sufficiently comprehensible to perform successfully a particular job, the TSE's construct and criterion-related validity are the issues relevant to this Comment. Validation by these methods would show the TSE to be accurate in determining whether an individual possesses sufficient oral cominunication skills to meet an einployer's reasonable requirements. ${ }^{152}$

Although ETS designed the Test of Spoken English as a context-free instrument to ineasure general speaking proficiency, ETS has established its construct- and criterion-related validity in specific contexts. For exainple, a nine-university study supported the TSE's validity in testing college and uinversity instructors, ${ }^{153}$ finding that "an instructor's TSE coinprehensibility score correlated with students' assessinent of the instructor's ability to handle cominon situations involving language skills." 154 Similarly, a study of the health care professions found TSE scores to aid significantly in predicting health professionals' assessments of exaininees' speaking abilities. ${ }^{155}$ Further, TSE scores show strong correlations with ratings given in the oral proficiency interview developed by the United States Department of State's Foreign Service Institute, the principal test of spoken language proficiency for more than three decades. ${ }^{156}$

149. Washington v. Davis, 426 U.S. 229, 247 n.13 (1976).

150. See 29 C.F.R. $\S 1607.5(B) .(C)$ (1992); see also Albemarle Paper Co. v. Moody, 422 U.S. 405, 430-31 (1975).

151. 29 C.F.R. § 1607.5(B); see also Washington, 426 U.S. at 247 n.13.

152. Because this Comment advocates using the TSE in litigation relating to the full range of employment contexts, content validity is not relevant.

153. See John L.D. Clark \& Spencer S. Swinton, Educational Testing Serv., The Test of Spoken ENglish as a Measure of Communicative Ability in English Medium INSTRUCTIONAL SETTINGS (1980). A copy of this report can be obtained from: TOEFL Research Reports, Order Services, P.O. Box 6161, Princeton, NJ 08541-6161.

154. ETS MANUAL, supra note 127, at 24.

155. Id.; see Donald E. Powers \& Charles W. Stansfield, Educational Testing Serv., The Test of Spoken English as a Measure of Communicative Ability in the Health Professions: Validation and Standard Setring (1983). A copy of this report can be obtained from: TOEFL Research Reports, Order Services, P.O. Box 6161, Princeton, NJ 085416161.

156. ETS MANUAL, supra note 127, at 23. The Foreign Service Institute (hereinafter FSI) oral 
The TSE, then, is an effective tool that provides an objective method of evaluatimg an individual's accent. Such a testing method would address the subjectivity problem infecting the adjudication of current accent discrimination cases by elimmating the need to rely on the subjective assessments of employers and fact finders, thereby lessening the possibility of speech and cultural stereotypes affecting the outcome. Moreover, the TSE would aid courts in drawing a rational line between plaintiffs whose speech is insufficiently comprehensible for the performance of a particular job and those who merely possess accents different from the accepted norm.

proficiency test consists of a fifteen to twenty-five minute structured conversation between the examinee and a trained interviewer who is either a native speaker or a near-native speaker of the test language. Since the FSI test can only be given to Foreign Service Officers who are training to work in consulates and embassies abroad (Telephone Interview, Recruitment Office, Foreign Service Institute, United States Department of State (Sept. 21, 1993)), it would be impractical to administer it for the purposes of accent discrimination cases.

Both the FSI interview and the TSE were administered to sixty foreign teaching assistants at state universities; there was a strong correlation between the FSI ratings and TSE scores. Id.; see Clark \& Swinton, supra note 153, at iii, 22.

FSI ratings are given on a scale of 1 to 5 , with a plus assigned to an examinee who fulfills most, but not all, of the requirements of the next highest level.

FSI Oral Proficiency Interview Levels

Level 1. Able to satisfy basic survival needs and minimum courtesy requirements.

Level 2. Able to satisfy routine social demands and limited work requirements.

Level 3. Able to speak the language with sufficient structural accuracy and vocabulary to participate effectively in most formal and informal conversations on practical, social, and professional topics.

Level 4. Able to use the language fiuently and accurately on all levels normally pertinent to professional needs.

Level 5. Speaking proficiency equivalent to that of a well-educated native speaker.

ETS MANUAL, supra note 127 , at 23 .

Approximate Relationship Between TSE Overall

$\begin{array}{lc}\text { Comprehensibility Scores and FSI Oral Proficiency Levels } \\ \text { FSI Level } & \text { TSE Score } \\ 1+ & 150-160 \\ 2 & 170-190 \\ 2+ & 200-210 \\ 3 & 220-240 \\ 3+ & 250-260\end{array}$

Id. at 21 (based on data gathered on 60 examinees in CLARK \& SwINTON, supra note 153).

$\begin{array}{lc} & \text { Relationship of TSE to FSI Ratings } \\ \text { TSE } & \text { FSI } \\ \text { Score } & \text { Rating } \\ \text { Pronunciation } & .77 \\ \text { Grammar } & .73 \\ \text { Fluency } & .76 \\ \text { Comprehensibility } & .76^{*}\end{array}$

Id. at 23 (TOEFL correlations omitted).

*The correlation between TSE comprehensibility and FSI ratings for all sixty [examinees] was .79. [The rest of the

.77

.73

76

correlations were based on 31 of the 60 examinees.] 
III

\section{Application of the Test of Spoken ENglish to Title VII LITIGATION}

This Comment proposes that parties and courts in accent discrimination cases use the TSE as an objective guide to determine whether a plaintiff's accent would impede her ability to perform a particular job. Introduction of the TSE would not fundainentally alter the structure of title VII hitigation in accent discrimmation cases; it would simply add an objective element to them. TSE scores that indicate sufficient language skills for a particular job should constitute evidence of discrimination, but not discrimination per se, while low scores could establish lack of discrimination or discriminatory intent.

Use of this objective test may have led to different results in the cases discussed above and would certaiuly influence the outcoine of future cases. More important than the result in any particular case, however, would be the TSE's effect of moving courts away from reliance on subjective assessments of a plaintiff's accent and the associated danger of prejudice and negative stereotypes affecting the outcome of accent discrimination litigation.

\section{A. Use of the TSE in Disparate Treatment Cases}

This Comment envisions that the TSE will enjoy its widest application in accent discrimination cases brought and analyzed under a disparate treatment theory, which describes the majority of accent discrimination cases. ${ }^{157}$ The TSE seems inore appropriate in the context of a disparate treatment clam1, focusing as such claims do on a single or discrete group of plaintiffs, since the TSE is desigued to gauge the comprehensibility of particular individuals. ${ }^{158}$ This is not to say, however, that the TSE cannot or ought not be used in the context of disparate impact claims; Part III.B discusses such a use.

\section{Plaintiff's Use of the TSE}

In establishing a case of accent discrimination, a plaintiff should be able to introduce her TSE scores as evidence in support of her claim. A high score would be a strong indicator that her accent does not impede her oral communication abilities. Most importantly, as a standardized test, the TSE allows the plaintiff to adduce objective evidence that her speech is comprehensible, thus circumventing the subjective judgments of the defendant and fact finder, as well as the risks of bias and stereotyping inherent in those judgments.

For example, plaintiff, a woman born in Thailand, applies for a posi-

157. See supra note 28.

158. See supra text accompanying notes 29-38. 
tion as a litigation associate $\mathrm{m}$ a major law firm. The employer, believing her accent would impede her ability to communicate with clients and fellow attorneys in the firm, does not hire her. She brings suit under a title VII disparate treatnient theory, alleging that she has been a victim of accent discrimination. She has the initial burden of establishing a prinia facie case of discrimination under the McDonnell Douglas Corp. factors: (1) that she has an identifiable national origin, (2) that she applied and was qualified for the job for which the employer was seeking applicants, (3) that she was rejected despite her qualifications, and (4) that, after her rejection, the position remained open and the employer continued to seek applicants from persons of the plaintiff's qualifications. ${ }^{159}$ Under the current system, the plamtiff would produce various credentials to establish lier qualifications for the job (for example, her law degree, menibership on the law review, inemberslip in the bar), as well as witnesses, including experts, testifying to the comprehensibility of her spoken Englisl.

Assurning the plaintiff establishes a prima facie case, the defendant would then have to articulate a legitimate, nondiscriminatory reason for not liiring the plaintiff despite her qualifications. To do so, the defendant must clearly establisl, througl admissible evidence, the reasons for the adverse employment decision. ${ }^{160}$ In this hypothetical, the defendant concedes that the plaintiff has the credentials to be a lawyer but argues that ler accent impedes her oral communication, an ability essential to being a litigator. To substantiate this claim, the defendant produces testimony, including expert testiniony, ${ }^{161}$ that the plaintiff's spoken English is insufficiently coinprehensible for the position. ${ }^{162}$

Once the defendant successfully rebuts the prima facie case, the plaintiff must then slow that the defendant's stated reason justifying the adverse hiring decision is merely pretextual. Plaintiff can do this directly, by slowing that the employer more likely than not had a discriminatory motive, or indirectly, by demonstrating that the employer's proffered rationale is unwortly of credence. The plaintiff has the ultiinate burden of persuading the trier of fact that the defendant intention-

159. See supra notes $30-31$ and accompanying text.

160. See supra notes $34-36$ and accompanying text.

161. Note that the TSE has the advantage of being a standardized test that objectively assesses the plaintiff's accent. This objective piece of evidence may be more helpful than the testimonies of expert witnesses regarding the plaintiff's intelligibility because the plaintiff's and defendant's experts will offer contradictory opinions.

If the TSE becomes a widely accepted tool in accent discrimination cases, its use may transform expert testimony in this type of litigation. The expert testimonies would probably then involvc the applicability or appropriateness of the TSE and the interpretation of its results in relation to the job in question, rather than in relation to the plaintiff's intelligibility.

162. Recall that the defendant need only produce evidence that the decision was not discriminatory. See supra notes 34-36 and accompanying text. 
ally discriminated against her. ${ }^{163}$ Here, the plaintiff asserts that the defendant's justification is pretextual. She contends that the defendant did not hire her because her accent indicated her foreign-born status, a trait the firm felt would be detrimental to its image. She points to her witnesses' opinions that she is coinprehensible and argues that the defendant is using her accent as a pretext for national origin discrimination.

Under the current systein, the fact finder would deterimine the factual issue of the plaintiff's coinprehensibility, based on each party's testiinony and on its own assessinent of the plaintiff's accent. At present, the most the fact finder may be able to do is histen to the plaintiff at trial and then decide the issue, or siniply accept the defendant's assessinent, as in Fragante. ${ }^{164}$

To lessen the danger that subjective assessments will allow bias to affect the outcoine of the case, the plaintiff can take the TSE, adducing her scores to buttress her clain of coinprehensibihty. For instance, if she scores 290 in overall comprehensibility, ${ }^{165}$ she can mtroduce this score into evidence to support her argument that the defendant's reason for denying her einployment was pretextual. ${ }^{166}$ This provides the fact finder with an objective benchmark by which to evaluate the plaintiff's accent, rather than relying on standardless, subjective assessinents. ${ }^{167}$

163. See supra notes $37-38$ and accompanying text.

164. See supra notes $90-92$ and accompanying text.

165. Such a score would indicate that the plaintiff is "[c]ompletely comprehensible in normal speech, with occasional grammatical or pronunciation errors in very colloquial phrases." ETS BulletiN, supra note 123, at 27.

166. If she knows that the defendant will raise an "unintelligible English" defense, the plaintiff can introduce these scores when establishing her prima facie case to show that she was sufficiently intelligible for the desired position. In such a case, the introduction of the TSE scores in the prima facie case would probably avert summary judgment against the plaintiff.

However, since the defendant need only meet a burden of production to rebut the prima facie case, and since the plaintiff must support her claim with other qualifications, the TSE score will become significant only when the trier of fact needs to rule on the validity of the "unintelligible English" defense.

167. High TSE scores will not by themselves guarantee the plaintiff's ultimate success. Certainly, the fact that the plaintiff scored highly on the TSE would constitute powerful evidence that the defendant's "unintelligible English" defense is a pretext for national origin discrimination. Nevertheless, under a disparate treatment theory, the plaintiff must establish discriminatory intent on the defendant's part, International Bhd. of Teamsters v. United States, 431 U.S. 324, 335 n.15 (1977), and the plaintiff's high TSE scores are just one element of her case. Moreover, the fact finder may or may not accord the plaintiff's TSE scores much weight, relying on subjective assessments in any event.

Finally, recall that a defendant can justify explicit national origin discrimination in limited circumstances by invoking the bona fide occupational qualification (BFOQ) exception. Title VII of the Civil Rights Act of $1964 \S 703(\mathrm{e}), 42$ U.S.C. $\$ 2000 \mathrm{e}-2(\mathrm{e})$ (1988); see supra notes $39-40$ and accompanying text. The defendant can thus prevail, even if the plaintiff has a perfect TSE score of 300 , by showing that the plaintiff's accent affects her ability to perform the job and relates to the essence or central mission of the defendant's business. See supra notes 41-43 and accompanying text. But because courts construe the BFOQ defense very narrowly, it will apply exclusively to cases where the defendant proves that only native speakers are qualified. 


\section{Defendant's Use of the TSE}

The TSE can be an effective tool for defendants as well as for plaintiffs. In defending an adverse employment decision, the employer may refer to the plaintiff's TSE scores to strengthen its claim that the plaintiff's accent would have impeded her ability to perform the job. That is, the defendant may argue that the job im question requires a higher level of communication skills than the plaintiff possesses, as evidenced by her TSE scores.

For example, after being denied a promotion because of her accent, a Laotian-born plaintiff brings a disparate treatment case under title VII, alleging national origin discrimination. The plaintiff, currently a junior associate in an engineermg firm, had sought a promotion to senior associate. In estabhishing a prima facie case under McDonnell Douglas, ${ }^{168}$ the plaintiff argues that she is fully qualified for the senior associate position based on her education, training, and experience. She further contends that her accent does not impede her oral communication ability. Expert witnesses substantiate the plaintiff's clain by attesting to her comprehensibility; plaintiff's colleagues testify that they have no problen understanding her and that the plaintiff has done very competent work.

Assuming that the plaintiff establishes the prima facie elements of McDonnell Douglas, the defendant must then articulate a legitiniate, nondiscriminatory reason for denying plaintiff the promotion. ${ }^{169}$ Thus, the defendant maintains that it requires duties of senior associatesincluding a great deal of client contact and nunierous oral presentations to colleagues- that it does not assign to junior associates. The defendant argues that the plaintiff, despite her competence as a junior associate, is not qualified for the promotion because her accent inipedes her ability to communicate at the level required of senior associates. To substantiate this claim, the defendant produces expert witnesses who testify that the plaintiff's accent renders her incomprehensible to ordinary listeners. The defendant also produces some of the plaintiff's colleagues to testify that they have had problems understanding her because of her accent.

The burden now shifts to the plaintiff to show that the defendant's reason is pretextual or not worthy of credence. ${ }^{170}$ In this case, the plaintiff argues that the defendant's reason lacks credence. To buttress this claim, the plaintiff refers to her credentials, her supervisor's statement approving the quality of her work, and her colleagues' testimonies that they comprehend her speech.

Under the current system, the defendant avoids liability if the fact finder agrees with its assessnient that the plaintiff's accent impedes her

168. See supra notes 30-33 and accompanying text.

169. See supra notes 34-36 and accompanying text.

170. See supra notes $37-38$ and accompanying text. 
ability to communicate. The assessments of both the fact finder and the employer are, of course, subjective. The risk to the employer of relying on the fact finder's ratification of its own determination can be lessened, and the prospects of avoiding liability improved, if the defendant were to adduce the plaintiff's TSE scores.

Procedurally, the parties can agree during discovery that the plaintiff will take the TSE and stipulate to her scores at trial. ${ }^{171}$ Assume the plaintiff scores 180 in overall comprehensibility, showing that she is "[g]enerally comprehensible but [makes] frequent errors in pronunciation, gramınar, choice of vocabulary items, ... with some pauses and rephrasing." 172 Such evidence would support the defendant's claim that it denied the plaintiff promotion because she cannot coininunicate at the level required of semor associates. Like the plaintiff in the earlier hypothetical, the defendant here has enployed the TSE to provide the court with an objective evaluation of the plaintiff's accent. This reduces the risk that the fact finder will subjectively and arbitrarily find the plaintiff comprehensible and thus impose liability on the defendant.

Alternatively, the defendant can avail itself of the TSE to determine when settlement would be a more prudent course of action than litigating the clain. For example, suppose the plaintiff scores 260 in overall comprehensibility, indicating complete comprehensibility in normal speech. ${ }^{173}$ Such a score would greatly weaken the defendant's clain that the plaintiff's accent would have impeded her ability to coinmunicate orally as a senior associate and should thus facilitate a reasonable and fair settlement.

\section{Courts' Use of the TSE}

Consistent with this Conment's proposal, the court should consider a plaintiff's TSE scores as part of the evidence before it in determining whether the plaintiff has fallen victim to national origin discrimination on account of her accent. Because TSE scores go directly to the factual issue before the court-whether the plaintiff's accent diminishes her ability to perform a job - the court should adınit the scores as evidence relevant to any accent discrimination case. ${ }^{174}$ Courts should view these

171. However, if a plaintiff refuses to take the TSE, a defendant may have to seek a court order compelling her to do so. The defendant may face some resistance from the courts until the TSE gains greater acceptance. Nevertheless, the plaintiff has put her accent at issue, and the defendant arguably has a right to test that accent. Thus, a court order regarding the TSE can be analogized to one compelling a medical or psychological examination of a plaintiff in a tort action.

172. ETS BULLETIN, supra note 123, at 27.

173. Id.

174. The Federal Rules of Evidence define "relevant evidence" as "evidence having any tendency to make the existence of any fact that is of consequence to the determination of the action more probable or less probable than it would be without the evidence." FED. R. EvID. 401. Relevant evidence is admissible, with certain exceptions, none of which encompass TSE scores. See FED. R. EvID. 402. 
scores as reflective of the plaintiff's qualifications, just as they would other indicators of competence, such as a college degree or professional certification.

The disadvantage of the TSE is that it is designed as a context-free instrument and therefore predicts only general speaking proficiency. ${ }^{175}$ Nevertheless, recall that academic institutions and professional licensing agencies use TSE scores to assess examinees' speaking proficiency with respect to job performance. ${ }^{176}$ Thus, although the TSE may not be designed for a specific job or employment field, its validity has been supported in fields requiring high-level communication skills. Similarly, courts can consider TSE scores in determining whether plaintiffs' oral communication skills are sufficient to perform specific jobs.

Despite this Comment's advocacy of the TSE's use in accent discrimination cases, no specific score on the TSE should alone determine a plamtiff's suitability for a particular job. Instead, courts should look at TSE scores in hight of the duties and requirements of the specific job in question, conducting a case-by-case analysis. For example, a fact finder may find a plaintiff who scores 180 in overall comprehensibility to be unqualified for a receptiomst's position but qualified for a job on an asseinbly line. Or, a fact finder may determine that, although a plaintiff scores 280 in overall comprehensibility, she lacks the proficiency to be a telemarketing associate because of the extensive telephone conımunications skills required. In its analysis, the court can rely on expert witnesses to explain the construction and validity of the TSE and the meaning of its scores, ${ }^{177}$ while employers and personnel experts niay describe the duties and the level of communication necessary for particular jobs.

The testimony of testing and personnel experts will assunie particular importance where a plaintiff's TSE scores are marginal. Unlike the two hypothetical cases discussed above, in which plaintiff's TSE scores were rather clear-cut with regard to whether the plaintiff was comprehensible, perhaps the majority of cases will involve plaintiffs whose scores fall somewhere short of outstanding. A plaintiff who scores between 150 and 200 in overall comprehensibility, for exainple, will pose difficulty for the court in determining whether her English is sufficiently intelligible. The fact finder will then have to weigh more carefully the plaintiff's scores in light of the duties and requirenents of the job, as well as the plaintiff's other qualifications.

175. See supra notes $153-56$ and accompanying text.

176. See supra notes $123-25$ and accompanying text.

177. FED. R. EVID. 702 ("If scientific, technical, or other specialized knowledge will assist the trier of fact to understand the evidence or to determine a fact in issue, a witness qualified as an expert by knowledge, skill, experience, training, or education, may testify thereto in the form of an opinion or otherwise."). 
But even in difficult cases, courts will not be completely handicapped in their interpretation of TSE scores. Such interpretations should be informed by the EEOC's directive to employers using standardized employinent tests: "Where cutoff scores are used, they should normally be set so as to be reasonable and consistent with normal expectations of acceptable proficiency within the work force." 178 Thus, since a plaintiff's accent reflects an immutable trait protected under title VII (i.e., national origin), courts considering such a trait with regard to the ability to perform a job should ask themselves whether their determinations of a plaintiff's comprehensibility are guided by "normal expectations and acceptable proficiency" of speech for the job in question, or by a preference for nonaccented Enghish.

\section{B. Use of the TSE in Disparate Impact Cases}

As noted above, since the TSE is designed to gauge the level of comprehensibility for each individual - a focus more appropriate to a disparate treatment claim-this Comment does not envision that the TSE will have wide applicability to disparate impact cases. That is not to say, however, that the TSE cannot also be an effective judicial tool in disparate impact cases.

For example, suppose a plaintiff brings a disparate impact claim against a radio station, alleging that the station has a policy of hiring only news reporters with native Midwestern accents. ${ }^{179}$ In a disparate impact case, the plaintiff establishes a prima facie case by showing that the defendant's selection device has a substantially disproportionate, adverse impact on her protected group. The defendant then has the burden of proving that the impact results from a "business necessity." 180 In this example, the plaintiff establishes her prima facie case simply by showing that the defendant's policy will necessarily screen out those whose national origin is outside the United States. Because this policy precludes people with ethnic accents from einployinent opportunities, the plaintiff has established a prima facie case of discrimination.

Assume now that the radio station fails to carry its burden of showing that it is a business necessity to put on the air only those individuals who have Midwestern accents. The court finds that such a criterion is merely an aesthetic requirement and is not related to job performance. Accordingly, the court will find that the defendant's einployment practice operates to exclude individuals in protected classes unnecessarily and

178. 29 C.F.R. § 1607.5(H) (1992).

179. Although a plaintiff can bring an accent discrimination case under a disparate impact theory under title VII, these cases do not appear to be very common and are not likely to become so. See supra note 28 and accompanying text.

180. See supra notes $45-46$ and accompanying text. 
is therefore prohibited. ${ }^{181}$ The court then issues an injunction mandating that the defendant not discriminate against future job applicants due to their national origin, as reflected by their accents. Nevertheless, sensitive to the fact that news reporters need a very high level of proficiency in spoken English, the court orders in its injunction that the defendant only has to consider applicants with accents that do not impede their ability to communicate. To guide the defendant in assessing applicants' accents, the court can order the defendant to require job applicants to submit TSE scores with their apphications. Given the demands of the job, the court can allow the defendant to set a mimimum score as high as $\mathbf{3 0 0}$ on overall comprehensibility before considering the applicant eligible for a position as a reporter.

\section{Fragante and Hou Revisited}

In Fragante, ${ }^{182}$ the court could have used the TSE to evaluate Mr. Fragante's oral commumication skills, rather than relying on its own assessments and the determination of interviewers who lacked training and who did not reliably test Mr. Fragante's communication skills. Under the proposal in this Comment, Mr. Fragante could lave taken the TSE and entered his scores into evidence. Based on these scores, the district court and the Ninth Circuit objectively could have evaluated whether Mr. Fragante's accent would have impeded his ability to perform the duties of a DMV clerk, rather than accepting the interviewers' subjective and arbitrary assessments. Similarly, in $\mathrm{Hou}^{183} \mathrm{Dr}$. Hou could lave taken the TSE and offered his scores into evidence on the issue of whether his accent impeded his teaching ability. Dr. Hou's introduction of his TSE scores into evidence would have obviated the need for the court to rely on the impressions of his students, tainted as they may have been with inproper biases, in order to assess the comprehensibility of Dr. Hou's accent.

\section{CONCLUSION}

In an effort to eradicate accent discrimination while balancing the legitimate needs of einployers, this Cominent calls for the introduction of an objective inethod of judging a plaintiff's accent in title VII litigation. The TSE is a professionally-developed and validated test that provides a rational way for courts to determine "intelligibility" and to avoid the influence, even if subconscious, of a bigoted preference for nonaccented English.

The United States' ethnic composition is constantly changing due to

181. See supra note 47 and accompanying text.

182. Fragante v. City of Honolulu, 699 F. Supp. 1429 (D. Haw. 1987), aff'd, 888 F.2d 591 (9th Cir. 1989), cert. denied, 494 U.S. 1081 (1990).

183. Hou v. Pennsylvania Dep’t of Educ., 573 F. Supp. 1539 (W.D. Pa. 1983). 
the flow of immigration. President Franklin Roosevelt once reminded Americans that "all of our people all over the country, all except the pure-blooded Indians, are immigrants, or descendants of immigrants, imcluding even those who came over here on the Mayflower." ${ }^{84}$ We do well to remember that this country was founded and built in large part by people from other lands, many of whom came here with a limited knowledge of English. The promise of equality and opportunity for immigrants should not be met with a closed economic door based on accent discrimination. 
